\title{
AN INVESTIGATION OF VARIOUS VARIABLES' EFFECTS ON MIDDLE SCHOOL STUDENTS' SKILLS OF RECOGNIZING FIGURE PATTERNS
}

\author{
Abdullah Cagri Biber, Abdulkadir Tuna, Lutfi Incikabi, Engin Yigit \\ Kastamonu University, Turkey \\ E-mail: acbiber@kastamonu.edu.tr, atuna@kastamonu.edu.tr, \\ lincikabi@kastamonu.edu.tr, ayigit@kastamonu.edu.tr
}

\begin{abstract}
The purpose of this study was to investigate the middle school students'skill of determining figure patterns in terms of the variables of gender, grade, and mathematics achievement. Being descriptive in nature, this study conducted through relational survey method. The participants of the study were total of 137 (fifth, sixth and seventh grade) students from a middle school placed in a province of northern Turkey. Among the results of the study were that the students'skills of detecting figure pattern did not considerably affected by their grade levels. However, in the figure pattern test female students were more successful than the males. Moreover, a positively-directed strong relationship was detected among the points which students get from mathematic lesson and their achievement in the figure pattern test. Based on the observations done, the middle school students 'mistakes in the test were mostly due to their lack of attention to the questions; they mostly focused on the drawing of the figure patterns and did not think the relation between the number of figures and steps.
\end{abstract}

Key words: figure patterns, mathematics education, middle school students.

\section{State of Art}

It is possible to coincide with a lot of descriptions for the concept of pattern in the literature. Souviney (1994) has described the pattern as "It is the systematic combination of the geometric shapes, voices, symbols or actions". Orton (1999) emphasizes that it is not easy to describe the pattern and this word can be used for shape, colour and even for the array of voices which are not special and open. Orton and Orton (1999) have described the patterns in another description that it is an approach which gets you to algebra. According to another description, pattern is a rule which is structured among the elements of a series of mathematical objects (numbers shapes, etc.) (Guerrero \& Rivera, 2002). Olkun and Toluk (2006) have used the statement as "poem which is composed of regularly arrayed objects". According to the description which takes place at the official web site of the Turkish Language Institution, pattern is described as actions and objects to follow each other developing in a regular way (TDK, 2012).

Mathematics teachers have clearly emphasized the importance of patterns in mathematics while describing the mathematics. They describe that mathematics as classification and the study of all possible patterns, pattern and searching regularity being one of the actions performed in the entirety mathematics, mathematics being searching the patterns and relations and they describe that the mathematics is simple the study of the patterns (Biggs \& Shaw, 1985; Mattershead, 1985; Sawyer, 1955; Williams \& Shuard, 1982, Cited in Orton, 1999). The properties such 
Abdullah Cagri BIBER, Abdulkadir TUNA, Lutfi INCIKABI, Engin YIGIT. An Investigation of Various Variables' Effects on Middle School Students' Skills of Recognizing Figure Patterns

\section{PROBLEMS \\ OF EDUCATION \\ IN THE $21{ }^{\text {st }}$ CENTURY Volume 55,2013 \\ 46}

as recognizing the patterns, continuing and constitution are very important abilities in seeing the mathematical relations, making generalization, perception of the regularity of mathematics (Burns, 2000). Zaskis and Liljedahl (2002) state that everything is the generalization of patterns in mathematics, particularly in algebra and therefore the patterns are the heart and core of mathematics. Feeling of numbering and mathematical invention develops with patterns for children. The patterns help children to develop firstly to order, calculate and setting. Afterwards, provide them to develop their thinking strategy for basic operations (Reys, Suydam, Lindquist, \& Smith, 1998). Hargreaves, Threlfall, Frobisher, and Shorrocks-Taylor (1999) have stated the importance of patterns of defending the necessity of analysing the patterns and relations which mathematics includes for understanding the structure of mathematics. Mathematics training researchers have handled the patterns subject from different perspectives and have reached to a common understanding that meeting the patterns at early ages for students, touching on the relation between the patterns and function concept will help them to develop the ability for solving problems as well as contributing to algebra thinking and learning algebra (Armstong, 1995; Bednarz, Kieran, \& Lee, 1996; English \& Warren, 1998; Kenney \& Silver, 1997; Lannin, 2005; NCTM, 2000; Orton \& Orton, 1999; Stacey, 1989). Generally, patterns being an essential concept (Bishop, Otto, \& Lubunski, 2001) for abstracting the mathematical thoughts and relations, generalization of relations, development of the ability of mathematical thinking, understanding mathematical concepts and the representatives which are reflecting those concepts, lead the development of the concepts for algebraic and functional thinking.

Patterns are generally analysed into two groups as varying patterns and repeating patterns. Olkun and Yeşildere (2007) define the repeating patterns as "patterns which are formed shifting the constant arrangement of the relation of terms." Threlfall (1999), define the repeating pattern as "patterns which continue as a cycle for some certain terms which is described as a repeating unit." Varying patterns are the ordering of a series of numbers, shapes or concrete materials in a regular way (Billstein, Libeskind, \& Lott, 2004). Olkun and Yeşildere (2007) have mentioned that the varying patterns are progress following patterns which are enlarging and shrinking among the terms. Apart from these classifications, they were analysed under different classifications. It is seen that patterns take place in a lot of studies in the generalization of patterns such as linear and non-linear (second degree and geometric series) patterns, numerical patterns, arithmetical patterns, geometric patterns and repeating patterns (Akkan, Çakıroğlu, Güven, \& Karataş, 2008; Amit \& Neria, 2008; Bishop, 2000; Feifei, 2005; Healy \& Hoyles, 1999; Lanin, 2005; Ley, 2005; Orton \& Orton, 1999; Rivera, 2007).

\section{Outline}

The purpose of the figure patterns is to support the student thinking with visible/geometric approach and by this visible approach to find an alternative way for the numbers. Also, figure patterns are seen much simpler than the patterns which are given in the symbolic form (Tanışlı, 2008). One of the supporters of this opinion is Bruner (1966) who states that a sequence is followed during the learning process of new opinions which is going from operational to imagination, from imagination to symbolic. One of the objectives of the figure pattern is the diversifying the solving of a problem.

Figure patterns are generally analysed into two groups so as the other patterns: Varying figure patterns and repeating figure patterns. Varying figure patterns are not only helpful to the students to change when necessary and constitution of a new step from one step, but also they are funny (Orton, Orton, \& Roper, 1999). Students may perceive the relations by catching the figural clues in figure patterns (Rivera \& Becker, 2005). By the way, for some students, questions which are containing figures provide them to comment the questions, arousing and simplifying them. The example of varying figure pattern is given in Figure 1. 


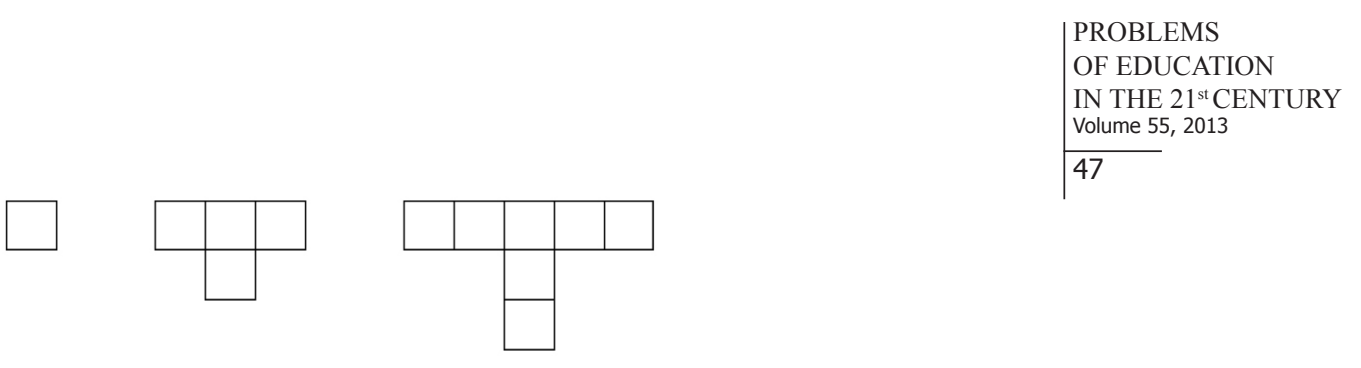

Figure 1: Sample of Varying Figure Pattern (Tanışlı, 2008).

Varying patterns may be simple or complicated according to the style they are given. The complexity of a repeating pattern may be performed by diversifying some of the symbols of the elements of the pattern (size, colour, etc.) and keeping some of the symbols as constant (Cathcart, Pothrer, Vance \& Bezuk, 2003). It is essential that the students explain a repeating pattern, similarities with the other patterns and their differences. For this purpose, regarding the repeating patterns, some activities should be achieved with the students such as copying the pattern, defining the repeating unit, continuing the pattern, completing the pattern, constituting the pattern. Such activities are important for mathematics in any class level and help them developing the connection between various representations particularly for young students and searching the similarities and differences between the representations (Warren \& Cooper, 2006). The example of repeating figure pattern is given in Figure 2.

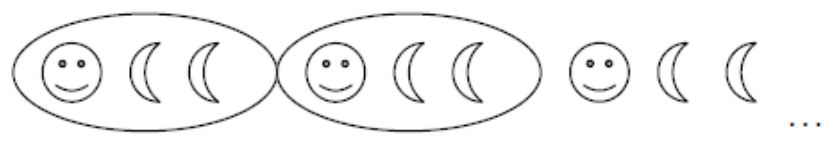

Figure 2: Sample of Repeating Figure Pattern (Tanışlı, 2008).

The patterns are found in the nature, art, music, trade, medicine and in even sociology. As it can be understood from the statement of "Mathematics discovers the pattern, comments and uses it" (Van De Walle, 2004), patterns exist in every area of our lives. The scope of visual perception dimension can be sampled with the statement that patterns exist even in wall paper, tile wainscot, traffics and television programmes (Billstein et al., 2004). If we give simple examples from our daily lives, sunrise and sunset, washing our faces and brushing our teeth in the mornings, going to the work, school, etc., occur in an array.

From this point of view, are the middle school students aware of those patterns and relation which we often face with in our daily lives? For investigating this, only figure patterns were used in this study. Therefore, the purpose of this study is to investigate the factors effecting primary school students' abilities of detecting figure patterns.

\section{Problem Sentence}

The question of "Which factors do have an effect on the middle school students' skills of recognizing figure patterns?" comprises the problem of the current study. In the light of this problem, the answers were searched for whether there is a considerable difference between the grade level of the students and their skill of recognizing figure patterns, whether there is a considerable difference between the gender of the students and their skill of recognizing figure patterns, and whether there is a relation between middle school students' skill of recognizing figure pattern and their achievement in mathematics. 
Abdullah Cagri BIBER, Abdulkadir TUNA, Lutfi INCIKABI, Engin YIGIT. An Investigation of Various Variables' Effects on Middle School Students' Skills of Recognizing Figure Patterns

\section{PROBLEMS \\ OF EDUCATION \\ IN THE $21^{\text {st }}$ CENTURY \\ Volume 55,2013 \\ Methodology of Research}

Being descriptive in nature, this study conducted as relational survey study. The relational survey studies are the investigation models which aim to determine the presence and degree between two or more variables (Gall, Gall, \& Borg, 1999; Gay 1987; Karasar, 1991, 2003). In this model descriptions are more oriented to the aim of determining the disparities among the aspects such as individual, object, etc. more than finding out the dimensions of the existing ones to certain standards.

\section{Participants of the Study}

The study was conducted with a total of 137 middle school students from a school placed in a province in the northern Turkey. The school operates under the Ministry of National Education giving education to the children of simple socioeconomic level families. Some demographic properties of the students who participated to the study were provided in Table 1.

Table 1. Demographic properties of the students who participated to the study.

\begin{tabular}{lllllll}
\hline & Male & \multicolumn{3}{c}{ Female } & \multicolumn{2}{c}{ General Total } \\
\cline { 2 - 7 } & $\mathrm{f}$ & $\%$ & $\mathrm{f}$ & $\%$ & $\mathrm{f}$ & $\%$ \\
Fifth Grade & 17 & 47 & 19 & 53 & 36 & 100 \\
Sixth Grade & 34 & 49 & 35 & 51 & 69 & 100 \\
Seventh Grade & 16 & 50 & 16 & 50 & 32 & 100 \\
General Total & 67 & 49 & 70 & 51 & 137 & 100 \\
\hline
\end{tabular}

\section{Data Collection Instrument and Data Analysis}

The item pool of Recognizing Figure Patterns Test (RFPT) was constructed based on the literature review. The opinions of three experts in the field of mathematics education were being applied to detect whether the problems were suitable for the purpose of measuring which exist in the prepared data compiling tool and whether they represented the area which was intended to be measured (Karasar, 2005). Some revisions have been implemented based on the experts' opinions. The final version of the RFPT test included 9 problems. The validity of language, level and content was provided for the questions prepared for this purpose. The RFPT was scored by giving 1 point to each correct answer which the student gave and giving 0 point to the wrong answer accordingly. In this test, correcting formula was not used.

After the compiled data was regulated, SPSS programme was used for the statistical analysis. According to the achieved results from the applied test, with the help of the programme material strength index and distinctive strength was found. By eliminating the 1 question the distinctive index of which is below 0.2 , one question was dropped and the evaluations were done over the 8 questions. "Cronbach Alfa" reliability coefficient was detected as 0.654 for RFPT. In the test, there were two different types of figure patterns: Varying pattern type and repeating pattern type. There were 4 questions for each pattern type. Regarding the pattern types taking place in the test, some sample questions were given below: 
Table 2. Figure Patterns taking place in the RFPT.

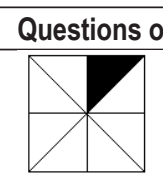

1 .

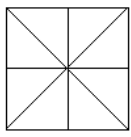

5.

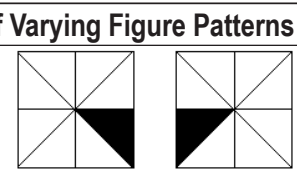

2.

3 .

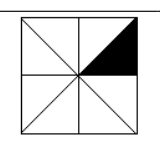

4.

I

Questions of Repeating Figure Patterns

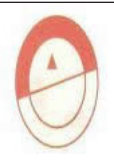

II

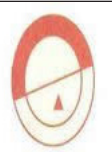

III

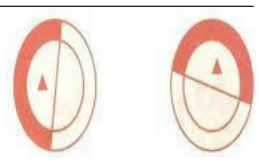

IV

Please mark the different figure among the figures given above and write the reason for that. (RFPT Item 3)

The black areas in the above figures take place in different parts of the same figure. According to that, please draw the figure which should be at the 5 th step. (RFPT Item 2)

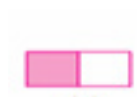

(1)

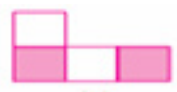

(2)

\section{?}

(3)

The figures given above were ordered based on a rule. Which figure is to come at the next (3) step? (RFPT Item 6)

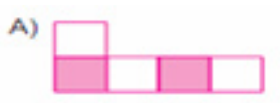

B)

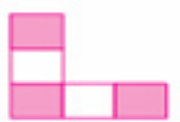

C)

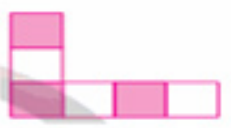

D)

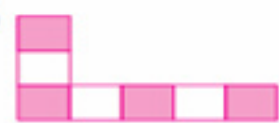

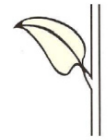

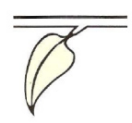

1

One of the figures given above is different than the others.

Which one is the different given below? (RFPT Item 9)

General characteristics of the research sample were determined by means of descriptive statistics and analysed in order to answer the related research question. In order to test the meaningfulness of the score differences between independent samples, the researchers utilized a one-way analysis of variance (ANOVA), independent-samples t-test, Scheffe and Pearson Correlation tests. The effect size for each analysis was also reported. During all computations, $\mathrm{p}$ value was taken as 0.05 .

\section{Results of Research}

Research results were provided under the sub-headings that were being in line with the research study.

Results Relating to the Relationship between Grade Level and Success in Recognizing Figure Patterns

The descriptive statistical values of data obtained from the RFPT according to the grade levels were given in Table 3. As it can be seen in Table 3, when the general points of the students regarding the figure pattern were reviewed according to the grade levels, it is observed that the average points of the seventh grade students are higher than those who were in the other grade levels. 
Abdullah Cagri BIBER, Abdulkadir TUNA, Lutfi INCIKABI, Engin YIGIT. An Investigation of Various Variables' Effects on Middle School Students' Skills of Recognizing Figure Patterns

OF EDUCATION

IN THE $21^{\text {st }}$ CENTURY Volume 55, 2013

Table 3. The average success points regarding the figure pattern test of the students according to the classes.

\begin{tabular}{llllll}
\hline & & N & Mean & Std. Deviation & Std. Error \\
\hline \multirow{4}{*}{ Varying patterns } & Fifth Grade & 36 & 2.6389 & 0.93052 & 0.15509 \\
& Sixth Grade & 69 & 2.5072 & 1.19587 & 0.14397 \\
& Seventh Grade & 32 & 2.8438 & 0.67725 & 0.11972 \\
& Total & 137 & 2.6204 & 1.02993 & 0.08799 \\
\hline \multirow{5}{*}{ Repeating patterns } & Fifth Grade & 36 & 2.6667 & 0.95618 & 0.15936 \\
& Sixth Grade & 69 & 2.8261 & 1.14989 & 0.13843 \\
& Seventh Grade & 32 & 3.3125 & 0.89578 & 0.15835 \\
& Total & 137 & 2.8978 & 1.06609 & 0.09108 \\
\hline \multirow{6}{*}{ General points } & Fifth Grade & 36 & 5.3056 & 1.58239 & 0.26373 \\
& Sixth Grade & 69 & 5.3333 & 2.16704 & 0.26088 \\
& Seventh Grade & 32 & 6.1563 & 1.19432 & 0.21113 \\
& Total & 137 & 5.5182 & 1.85545 & 0.15852 \\
\hline
\end{tabular}

A one-way analysis of variance (ANOVA) was used to determine whether the difference of average points is statistically meaningful or not. The obtained results were given in Table 4 . The students' grade levels have not leaded to a considerable discrepancy over the general average points regarding the figure patterns test $[\mathrm{F}(2 ; 134)=2.526 ; \mathrm{p}>0.05]$ and the average points they get from the questions of varying figure pattern type $[F(2 ; 134)=1.178 ; p>0.05]$. However, it was observed that there was considerable difference between the grade levels in terms of the average scores belonging to repeating figure pattern.

Table 4. The results of the ANOVA test regarding the average success points of the figure pattern test of the students according to the classes.

\begin{tabular}{lllllll}
\hline & & Sum of Squares & df & Mean Square & F & Sig. \\
\hline \multirow{3}{*}{ Varying patterns } & Between Groups & 2.492 & 2 & 1.246 & 1.178 & 0.311 \\
& Within Groups & 141.771 & 134 & 1.058 & & \\
& Total & 144.263 & 136 & & & \\
\hline \multirow{3}{*}{ Repeating patterns } & Between Groups & 7.781 & 2 & 3.891 & 3.552 & 0.031 \\
& Within Groups & 146.788 & 134 & 1.095 & & \\
& Total & 154.569 & 136 & & & \\
\hline \multirow{3}{*}{ General points } & Between Groups & 17.013 & 2 & 8.507 & 2.526 & 0.084 \\
& Within Groups & 451.191 & 134 & 3.367 & & \\
& Total & 468.204 & 136 & & & \\
\hline
\end{tabular}

Scheffe analysis which is one of the Post Hoc tests was used for the purpose of determining the favor of this discrepancy to which grade. The results of this analysis were presented in Table 5. It is observed that the average scores of the repeating figure pattern was considerably higher for the students who are in seventh grade when compared with the fifth graders. 
Abdullah Cagri BIBER, Abdulkadir TUNA, Lutfi INCIKABI, Engin YIGIT. An Investigation of Various Variables' Effects on Middle School Students' Skills of Recognizing Figure Patterns

Table 5. The results of the Post Hoc test of the students according to the classes regarding the repeating figure patterns.

\begin{tabular}{llllll}
\hline \multicolumn{1}{l}{ Dependent Variable } & & $\begin{array}{l}\text { Mean Difference } \\
(\mathrm{I}-\mathrm{J})\end{array}$ & Std. Error & Sig. \\
& \multirow{2}{*}{ 5.class } & 6.class & -0.15942 & 0.21518 & 0.760 \\
& & 7.class & $-0.64583^{*}$ & 0.25429 & 0.043 \\
\multirow{2}{*}{ Repeating patterns } & \multirow{2}{*}{ 6.class } & 5.class & 0.15942 & 0.21518 & 0.760 \\
& & 7.class & -0.48641 & 0.22385 & 0.098 \\
& \multirow{2}{*}{ 7.class } & 5.class & $0.64583^{*}$ & 0.25429 & 0.043 \\
& & 6.class & 0.48641 & 0.22385 & 0.098 \\
\hline
\end{tabular}

* The mean difference is significant at the 0.05 level.

Based on the results obtained from the tables, students' grade level has an effect on students' achievement of recognizing patterns, especially in the repeating form. This situation can be explained the fact that students' experience, knowledge, and their ability of problem solving, that is highly correlated with patterns in mathematics, improves and increase by the grade level.

Results Relating to the Relationship between Gender and Success in Recognizing Figure Patterns

The descriptive statistical values according to the genders of the students were given in Table 6 . The average scores of the RFPT of the female students were found higher than the male students. It is observed from Table 6 that the general average score of the female students ( $\bar{x}=5.8714 \bar{x}=5,8714$ ) was considerably higher than the male students $(\bar{x}=5.1493)$. However, whether those results are meaningful or not were assessed according to the independent- samples t-test (Table 7). Accordingly, when general scores were reviewed; it is observed that there was a considerable difference $(\mathrm{p}<0.05)$ among the general average scores according to the gender variable. Similarly, it is also seen that the average score of the female students for the varying figure pattern type $(\bar{x}=2.8857 \bar{x}=2,8857)$ was also higher than the male students $(\bar{x}=2.3433 \bar{x}=2,3433)$; and this difference was meaningful $(\mathrm{p}<0.05)$. Furthermore, although the average score of the female students for the repeating figure pattern items $(\bar{x}=2.9857)$ was also higher than the male students $(\bar{x}=2.8060)$, this score difference was not found statistically important $(\mathrm{p}>0.05)$. Putting both together, one may conclude that the female students were better in determining varying figure pattern than the males.

Table 6. The average success points of the students according to the genders regarding the figure pattern test.

\begin{tabular}{llllll}
\hline & Gender & N & Mean & Std. Deviation & Std. Error Mean \\
\hline \multirow{2}{*}{ Varying patterns } & Female & 70 & 2.8857 & 0.89350 & 0.10679 \\
& Male & 67 & 2.3433 & 1.09478 & 0.13375 \\
\multirow{2}{*}{ Repeating patterns } & Female & 70 & 2.9857 & 0.98530 & 0.11777 \\
\multirow{2}{*}{ General points } & Male & 67 & 2.8060 & 1.14467 & 0.13984 \\
& Female & 70 & 5.8714 & 1.62339 & 0.19403 \\
& Male & 67 & 5.1493 & 2.01700 & 0.24642 \\
\hline
\end{tabular}


Abdullah Cagri BIBER, Abdulkadir TUNA, Lutfi INCIKABI, Engin YIGIT. An Investigation of Various Variables' Effects on Middle School Students' Skills of Recognizing Figure Patterns

OF EDUCATION

IN THE $21^{\text {st }}$ CENTURY Volume 55, 2013

Table 7. The Results of Independent-Samples t- Test of the Average Success Points for the Figure Pattern test according to the Gender of the Students.

\begin{tabular}{|c|c|c|c|c|c|c|}
\hline & & \multicolumn{2}{|c|}{$\begin{array}{l}\text { Levene's Test for } \\
\text { Equality of Variances }\end{array}$} & \multicolumn{3}{|c|}{ t-test for Equality of Means } \\
\hline & & $\mathbf{F}$ & Sig. & $t$ & df & Sig. (2-tailed) \\
\hline \multirow{2}{*}{ Varying patterns } & Equal variances assumed & 6.036 & 0.015 & 3.183 & 135 & 0.002 \\
\hline & Equal variances not assumed & & & 3.169 & 127.436 & 0.002 \\
\hline \multirow{2}{*}{ Repeating patterns } & Equal variances assumed & 1.903 & 0.170 & 0.986 & 135 & 0.326 \\
\hline & Equal variances not assumed & & & 0.983 & 130.180 & 0.327 \\
\hline \multirow{2}{*}{ General points } & Equal variances assumed & 1.723 & 0.192 & 2.313 & 135 & 0.022 \\
\hline & Equal variances not assumed & & & 2.303 & 126.646 & 0.023 \\
\hline
\end{tabular}

Although the stereotypes about female inferiority in mathematics, previous research showed that gender differences in mathematics performance were very small and, depending on the sample and outcome measures, sometimes favoured boys and sometimes favoured girls.

\section{Results Relating to the Relationship between Mathematics Achievement and Success in Recognizing Figure Patterns}

Table 8 shows the results of the Pearson Correlation test which was done for the purpose of investigating whether there was a relation between the students' scores for the figure pattern and their grades in the mathematics classes. It is seen form the table that there exists a positively directed moderate relationship between students' mathematics achievement and their general average scores for the RFPT ( $\mathrm{r}=0.449)$, for the varying figure pattern items $(\mathrm{r}=0.456)$, and for the repeating figure pattern items $(\mathrm{r}=0.340)$.

Table 8. Relation between the average success points of the students for the figure pattern and mathematics success points.

\begin{tabular}{lllll}
\hline & & Varying patterns & Repeating patterns General points \\
\hline \multirow{3}{*}{$\begin{array}{llll}\text { Grades in mathematics } \\
\text { lessons }\end{array}$} & Pearson Correlation & $0.456^{* *}$ & $0.340^{* *}$ & $0.449^{* *}$ \\
& Sig. (2-tailed) & 0.000 & 0.000 & 0.000 \\
& $N$ & 137 & 137 & 137 \\
** Correlation is significant at the 0.01 level (2-tailed).
\end{tabular}

Overall mathematics achievement is highly correlated with success in mathematical problem solving (Bryant, Bryant, \& Hammill, 2000), and the need to develop proficiency in problem solving is relevant to students' success in such mathematical concepts as patterns that require from students to use the skills of reasoning and problem solving. 


\section{Discussion}

The following results were achieved in this research according to the obtained findings which was done for the purpose of investigating the capabilities of the primary school students regarding figure patterns depending on which factors. The results were limited to the participants of the study and to the instrument that were being used to collect data.

The general average scores of 137 primary school students in this test who participated to the research and the average scores they get from the questions on varying figure pattern type do not indicate a considerable discrepancy according to the students' grade levels. However, the scores obtained from the questions on the repeating figure pattern type for the seventh grade students were higher than the fifth graders. This situation can be explained as seventh grade students are more educated than the students who were in the fifth grade, because it can be thought that 5 th class students might not paid the required attention to the repeating figure pattern questions. Furthermore, when the pedagogic importance of the figure patterns for getting through the functions (Kabael \& Tanışl1, 2009) is considered, getting mentally ready for learning the function concept is most for the 7th class students.

In the figure pattern test which requires attention and capability, it was found out that female students were more successful than the males. Although literature provides evidence of gender similarities in mathematics achievement (Hedges \& Nowell, 1995; Hyde, Fennema, \& Lamon, 1990; Hyde, Lindberg, Linn, Ellis, \& Williams, 2008), numerous studies show that girls earn better grades in mathematics courses through the end of high school (Dwyer \& Johnson, 1997; Kenney-Benson, Pomerantz, Ryan, \& Patrick, 2006; Kimball, 1989). Therefore, especially in mathematics lessons; it can be said that it would be useful to do some activities for increasing the attention level of the male students.

A positively-directed strong relationship was detected among the points which students get from mathematic lesson and the points which they get from the RFPT. A recommendation can be done here for the mathematics teachers. According to the observations of the researcher, students have solved this test willingly and happily. Among the main principles stated in the mathematics teaching programs in Turkey and around the world (such as NCTM) were to develop positive attitudes towards mathematics, use multiple representations, and to improve students such cognitive skills as problem solving, critical thinking, reasoning (MONE, 2013; NCTM, 2000). Within these regards, using figure patterns of different type would increase students' recognition of the figure patterns and their achievement in mathematics, support their attitudes toward mathematics and improve their cognitive skills.

Based on the observations done, the primary school students' mistakes in the RFPT mostly were due to their lack of attention to the questions; they mostly focused on the drawing of the figure patterns and did not think the relation between the number of figures and steps. Moreover, the errors might also be given as their perception of the rule of pattern as the difference between the two terms, namely their effort to solve all of the questions with the same strategy and as a result achieving a wrong generalization. Similar findings can be seen in the study of MacGregor and Stacey (1997).

\section{Conclusions}

This study investigated middle students' skills of recognizing figure patterns of varying type and repeating type. The results obtained in the current study indicated were limited to the participants and the instrument that was used to collect data from the participants.

Being in line with the literature implying a positive correlation between using complex skills (such as problem solving and reasoning) and age (or grade level), this study have also 
Abdullah Cagri BIBER, Abdulkadir TUNA, Lutfi INCIKABI, Engin YIGIT. An Investigation of Various Variables' Effects on Middle School Students' Skills of Recognizing Figure Patterns

\section{PROBLEMS \\ OF EDUCATION \\ IN THE $21^{\text {st }}$ CENTURY Volume 55,2013 \\ 54}

indicated that students' grade level have a contribution to the skill of recognizing figure pattern that requires higher order of process skills such as problem solving. Within this regard, a classroom environment that uses problem solving strategies or focuses on problem-based teaching would robust students' understanding of patterns. Moreover, the result that students' success in figure pattern is correlated their success in mathematics supports the past evidences showing that good problem solvers also do better in mathematics.

The results obtained in this study would be beneficiary for teachers to plan their activities while teaching patterns in mathematics. Moreover, the results obtained from this study would also be useful for curriculum designers to judge what activities at different grade levels could improve students' skills of recognizing figure patterns. Future studies that investigate uses of figure patterns at different school settings (such as elementary school or high school) would be beneficiary to reinforce the results obtained in the current study. Moreover, an examination of the textbooks in terms of their inclusion of patterns would also contribute to the results of this study.

\section{References}

Akkan, Y., Çakıroğlu, Ü., Güven, B., \& Karataş, İ. (13-15 November 2008). Comparing the adequacy of the primary school second level students belonging to the pattern types in different formats. Notification handout presented in VII. Mathematics Symposium, İzmir.

Amit, M., \& Neria, D. (2008). Rising to the challenge: Using generalization in pattern problems to unearth the algebraic skills of talented pre-algebra students. ZDM Mathematics Education, 40, 111-129.

Armstrong, B. E. (1995). Teaching patterns, relationships and multiplication as worthwhile mathematical tasks. Teaching Children Mathematics, 1, 446-450.

Bednarz, N., Kieran, C., \& Lee, L. (1996). Approaches to Algebra. London: Kluwer Academic Publisher.

Billstein, R., Libeskind, S., \& Lott, J. W. (2004). A problem solving approach to mathematics for elementary school teachers. 8th Ed-Reading, Massachusetts: Addison- Wesley.

Bishop, J. W. (2000). Linear geometric number patterns: Middle school students' strategies. Mathematics Education Research Journal, 12 (2), 107-126.

Bishop, J. W., Otto, A. D., \& Lubunski, C. A. (2001). Promoting algebraic reasoning using students' thinking. Mathematics Teaching in the Middle School, 6 (9), 508-514.

Bryant, D. P., Bryant, B. R., \& Hammill, D. D. (2000). Characteristic behaviors of students with LD who have teacher-identified math weaknesses. Journal of Learning Disabilities, 33, 168-177.

Bruner, J. S. (1966). Toward a theory of instruction (Vol. 59). Belknap Press.

Burns, M. (2000). About teaching mathematics. A-K 8 research. 2nd Ed-Sausaluto, California: Math Solutions Publication

Cathcart, W. G., Pothier, V. M., Vance, T. H., \& Bezuk, N. S. (2003). Learning mathematics in elementary and middle schools. 3rd Ed-Upper Saddle River, N.J: Merrill/Prentice Hall.

Dwyer, C. A., \& Johnson, L. M. (1997). Grades, accomplishments and correlates. In W. A. Willingham \& N. S. Cole (Eds.), Gender and fair assessment (pp. 127-156). Mahwah, NJ: Erlbaum.

English, L., D., \& Warren, E. A. (1998). Introducing the variable through pattern exploration. Mathematics Teacher, 912, 166-170.

Feifei, Y. (2005). Diagnostic Assessment of Urban Middle School Student Learning of Pre-algebra Patterns. Doctoral Dissertation, Ohio State University, USA.

Gall, J., Gall, M. D., \& Borg, W. R. (1999). Applying educational research. New York: Longman.

Gay, L. R. (1987). Educational research competencies for analysis and application. New York: Macmillan Publishing Company.

Guerrero, L., \& Rivera A. (2002). Exploration of patterns and recursive functions. Proceedings of the Annual Meeting of the North American Chapter of the International Group for the Psychology of Mathematics Education (24th, Athens, Georgia, October 26-29), 1-4. 262-272. 
Hargreaves, M., Threlfall, J., Frobisher, L., \& Shorrocks-Taylor, D. (1999). Children's strategies with linear and quadratic sequences. In A. Orton (Ed.), Pattern in the teaching and learning of mathematics (pp. 67-83). London: Cassell.

Healy, L., \& Hoyles, C. (1999). Visual and symbolic reasoning in mathematics: Making connections with computers. Mathematical Thinking and Learning, 1, 59-84.

Hedges, L. V., \& Nowell, A. (1995, July 7). Sex differences in mental test scores, variability, and numbers of high-scoring individuals. Science, 269, 41-45.

Hyde, J. S., Fennema, E., \& Lamon, S. (1990). Gender differences in mathematics performance: A metaanalysis. Psychological Bulletin, 107,139-155.

Hyde, J. S., Lindberg, S. M., Linn, M. C., Ellis, A., \& Williams, C. (2008, July 25). Gender similarities characterize math performance. Science, 321, 494-495.

Kabael, T., \& Tanışl1, D. (2010). Teaching from Patterns to Functions in Algebraic Thinking Process. Elementary Education Online, 9 (1), 213-228.

Karasar, N. (1991). Bilimsel araştırma yöntemi. Ankara: Sanem Matbaacılık.

Karasar, N. (2003). Bilimsel Araştırma Yöntemi. Ankara: Nobel Yayın Dağıtım.

Karasar, N. (2005). Bilimsel Araştırma Yöntemi: Kavramlar, İlkeler ve Teknikler. Ankara: Nobel Yayıncilik.

Kenney-Benson, G., Pomerantz, E., Ryan, A., \& Patrick, H. (2006). Sex differences in math performance: The role of children's approach to schoolwork. Developmental Psychology, 42, 11-26.

Kenney, P. A. \& Silver, E. A. (1997). Probing the foundations of algebra: Grade 4 pattern items in NAEP. Teaching Children Mathematics, 3, 268-274.

Kimball, M. M. (1989). A new perspective on women's math achievement. Psychological Bulletin, 105, $198-214$.

Lannin, J. K. (2005). Generalization and justification: The challenge of introducing algebraic reasoning through patterning activities. Mathematical Thinking and Learning, 73 (7), 231-258.

Ley, A. F. (2005). A Cross- sectional investigation of elementary school students' ability to work with linear generalizing patterns: The impact of format and age on accuracy and strategy choice. Master Dissertation, Toronto University, Canada.

Macgregor, M., \& Stacey, K. (1997). Ideas about symbolism that students bring to algebra. The Mathematics Teacher, 90 (2), 110-113.

MONE, 2013. Middle school mathematics teaching program. Ankara. MEB Publishing House.

NCTM. (2000). Principles and standards for school mathematics. Reston, VA: NCTM.

Olkun, S., \& Toluk-Uçar, Z. (2006). Modern approaches to primary school mathematics teaching. Ankara: Ekinoks Yayınları.

Olkun, S., \& Yeşildere, S. (2007). Basic Mathematics for the candidates of class teachers 1. Ankara: Maya Akademi.

Orton, A. (1999). Preface. In A. Orton (Ed.), Pattern in the teaching and learning of mathematics. (viiviii). London and New York: Cassell.

Orton, A., \& Orton, J. (1999). Pattern and the approach to algebra. In A. Orton (Ed.), Pattern in the teaching and learning of mathematics (104-120). London and New York: Cassell.

Orton, J., Orton, A., \& Roper, T. (1999). Pictorial and practical contexts and the perception of pattern. In A. Orton (Ed.), Pattern in the teaching and learning of mathematics (121-136). London and New York: Cassell.

Reys, R. E., Suydam, M. N., Lindquist, M. M., \& Smith. N. L. (1998). Helping children learn mathematics. (5th Ed.). Boston: Allyn and Bacon.

Rivera, F. D., \& Becker, J. R. (2005). Figural and numerical modes of generalizing in algebra. Mathematics Teaching in the Middle School, 11 (4), 198-203.

Rivera, F. (2007). Visualizing as a mathematical way of knowing: Understanding figural generalization. Mathematics Teacher, 101 (1), 69-75.

Souviney, R. J. (1994). Learning to teach mathematics. New York: Merrill

Stacey, K. (1989). Finding and using patterns in linear generalizing problems. Educational Studies in Mathematics, 20, 147-164.

Tanış1, D. (2008). Identifying the primary school 5th grade students' comprehension and grasp manners regarding patterns, Doctoral Dissertation, Anadolu University Graduate School of Education, Eskişehir. 
Abdullah Cagri BIBER, Abdulkadir TUNA, Lutfi INCIKABI, Engin YIGIT. An Investigation of Various Variables' Effects on Middle School Students' Skills of Recognizing Figure Patterns

PROBLEMS

OF EDUCATION

IN THE $21^{\text {st }}$ CENTURY

Volume 55,2013

56

TDK (2012). Large Turkish Dictionary. Ankara.

Threlfall, J. (1999). Repeating patterns in the early primary years. In A. Orton (Ed.). Pattern in the teaching and learning of mathematics (pp. 18-30). London and New York: Cassell.

Van De Walle, J. A. (2004). Elementary and Middle School Mathematics. 5th Ed- Boston: Allyn and Bacon.

Warren, E., \& Cooper, T. (2006). Using repeating patterns to explore functional thinking. APMC, 11 (1), 9-14.

Zaskis, R., \& Liljedahil, P. (2002). Generalization of patterns: The tension between algebraic thinking and algebraic notation. Educational Studies in Mathematics, 49, 379-402.

Advised by Laima Railiene, University of Siauliai, Lithuania

Received: June 12, 2013

Accepted: June 23, 2013

Abdullah Cagri Biber

PhD., Assistant Professor, Faculty of Education, Kastamonu University, Akteke Mahallesi, C Block, Floor 3, No: 17, Kastamonu, 37200, Turkey

E-mail: acbiber@kastamonu.edu.tr

Abdulkadir Tuna

PhD., Assistant Professor, Faculty of Education, Kastamonu University, Akteke Mahallesi, C Block, Floor 3, No: 17, Kastamonu, 37200, Turkey

E-mail: atuna@kastamonu.edu.tr

Lutfi Incikabi

PhD., Assistant Professor, Faculty of Education, Kastamonu University, Akteke Mahallesi, C Block, Floor 3, No: 17, Kastamonu, 37200, Turkey

E-mail: lincikabi@kastamonu.edu.tr

Engin Yigit

Graduate Student, Faculty of Education, Kastamonu University, Akteke Mahallesi, C Block, Floor 3, No: 17, Kastamonu, 37200, Turkey

E-mail: ayigit@kastamonu.edu.tr 